\title{
Dental Undergraduate Student Perceptions on Formative and Summative Assessment - A Cross Sectional Study
}

\author{
Deesha Kumari ${ }^{1}$, Bless Annie Philip², Thara Chandran ${ }^{3}$ \\ ${ }^{1}$ Department of Public Health Dentistry, Nitte (Deemed to Be University), AB Shetty Memorial Institute \\ of Dental Sciences (ABSMIDS), Mangalore, Karnataka, India. ${ }^{2}$ Department of Public Health Dentistry, \\ Nitte (Deemed to Be University), AB Shetty Memorial Institute of Dental Sciences (ABSMIDS), \\ Mangalore, Karnataka, India. ${ }^{3}$ Department of Public Health Dentistry, Nitte (Deemed to Be University), \\ AB Shetty Memorial Institute of Dental Sciences (ABSMIDS), Mangalore, Karnataka, India.
}

\section{ABSTRACT}

\section{BACKGROUND}

With a paradigm shift in the present-day curriculum, students are exposed to a more competitive mode of learning which judges them on theoretical knowledge rather than practical competencies in the field. While the curriculum developers are still incongruous about harmonizing the process of Formative Assessment (FA) and Summative Assessment (SA), initiating any change in the curriculum dictates the need for obtaining feedback from all the stakeholders. The present study was thus conducted to obtain dental undergraduate students' perceptions on FA and SA.

\section{METHODS}

A cross-sectional study was conducted among 143 third and final year BDS students in a private institution in Mangalore. Data was collected using an online, selfadministered validated 15 item closed-ended questionnaire distributed over 6 domains. The difference in opinion of students regarding formative and summative assessment was analysed using Students paired t test.

\section{RESULTS}

73.4\% of students preferred Formative Assessment over Summative Assessment. $50.3 \%$ students felt that Formative Assessment helped them in long term learning. Majority of the students were in consensus that Formative Assessment enhanced student learning $(14.14+3.44)$ in comparison to Summative Assessment $(13.71+$ 3.47). However, students felt that both Formative and Summative Assessments increased their workload and affected their personal life. 58.7\% students preferred short essay questions and $58.7 \%$ students preferred Objective Structured Clinical Examination (OSCE) as a mode of assessment in theory and practical examinations respectively.

\section{CONCLUSIONS}

Majority of the students preferred Formative Assessment for various reasons. Though it resonates their preference to Formative Assessment, it is still not widely practiced since it is resource intensive and time consuming. In this direction, curriculum developers should initiate the need for embedding Formative and Summative Assessment in the dental curriculum.

\section{KEY WORDS}

Formative, Summative, Assessment, Dental Undergraduates
Corresponding Author: Dr. Bless Annie Philip, Tutor, Nitte (Deemed to Be University), $A B$ Shetty Memorial Institute of Dental Sciences (ABSMIDS), Department of Public Health Dentistry, Mangalore-575018,

Karnataka, India.

E-mail:philip.bless@gmail.com

DOI: $10.14260 /$ jemds/2020/513

How to Cite This Article:

Kumari D, Philip BA, Chandran T. Dental undergraduate student perceptions on formative and summative assessment- a cross sectional study. J Evolution Med Dent Sci 2020;9(33):2367-2371, DOI: 10.14260/jemds/2020/513

Submission 12-05-2020,

Peer Review 08-07-2020,

Acceptance 15-07-2020,

Published 17-08-2020.

Copyright (C) 2020 JEMDS. This is an open access article distributed under Creative Commons Attribution License [Attribution 4.0 International (CC BY 4.0)] 


\section{BACKGROUND}

Assessment drives learning. From time immemorial, assessment has been an integral part of the curriculum moulding students' future in different sectors of education worldwide. It bears a prime role in any form of education as it sets the criteria benchmark for quality learning.[1] In Medical and Dental education particularly the stakes are high, as the assessment process is unduly related to the attainment of competent doctors who will be serving the community bearing the key responsibility of Health promotion.

Various forms of assessment systems are followed like Diagnostic, Formative, Summative, Non-referenced, Criterion Referenced, Interim/ Benchmark, amongst which Formative and Summative Assessments are widely used worldwide. Formative Assessment known as Assessment for Learning is an instructional process with dual purpose. It informs the teachers about the student's progress and is an asset in analysing the effectiveness of the instructional method and further strengthening it. In addition, students gain an understanding of their progress in the unit, thus epitomizing their strengths and weakness. However it can be time consuming and resource intensive due to which educational bodies tend to favour a more objective assessment.[2] On the other hand, Summative Assessment known as Assessment of Learning is a measurable way of determining the pros and cons of the training process but it may not always reflect the students' performance.[3]

In India the Dental Education is regulated by the Dental Council of India which regulates the Dental education which conceptualizes and develops a training framework and evaluation format which is adopted and modified by the respective universities for the betterment of student learning. ${ }^{4]}$ In recent times, there has been a shift from the traditional mode of assessment to a more learning centred assessment. In the earlier years' students were exposed to summative assessment with a final examination which would narrate their promotion to the corresponding higher standard. With the changing trend in education, students are now exposed to a more formative type of assessment which indulges them in deep learning. However a fully-fledged Formative Assessment system is still absent in the present Dental education system owing to various constraints like resources, faculty inhibitions and lack of time.[5,6]

A change in the evaluation process demands all the Stakeholders to be prepared to support and facilitate this rational shift to meet the challenge of aligning it with the vision of the educational institution to emphasize higher order, complex thinking skills to enhance the goal of student learning. In this direction, an effective school evaluation and assessment Development Cell should include all stakeholder groups (students, parents, teachers, administrators, and the general public) who should promptly entail in the Conceptualization and implementation of the evaluation system. ${ }^{[6]}$

In India most of the current literature addresses the role of Faculty, Students and other stakeholders in providing the basic descriptions of the assessment process, case studies of successfully implemented assessment programs, and advice to administrators on how to implement assessment programs. ${ }^{[7,8]}$ Students are the prime stakeholders in any educational forum as the effects of assessment are directly related to their future goals. Limited literature worldwide has focused on assessing the students' perceptions on Formative and Summative Assessment. Thus, the present study aims to assess students' perceptions on Formative and Summative Assessment in a private dental institution in India.

\section{METHODS}

The study employed a Cross sectional design and was conducted for a duration of 1 month during May 2020. All the students pursuing $3^{\text {rd }}$ BDS and $4^{\text {th }}$ BDS Program in the institution were included in the study employing the Total Enumeration Sampling Technique. Ethical Clearance was obtained from the Institutional Ethical Committee (ABSM/EC/3/2020). The students not providing consent were excluded from the study. The data was obtained through an Online Data Collection Process, using a Validated Selfadministered Questionnaire in English language wherein the participant's names were not recorded; instead they were assigned code numbers to ensure anonymity. The Questionnaire was validated by a team of 6 Dental Public Health Professionals and 4 Undergraduate Students for Face and Content Validity. The questionnaire consisted of 15 closed ended questions distributed over 4 domains namely Personal Details (3 Questions), Enhanced learning and competencies (4 Questions), Merits and Demerits of Assessment (4 Questions) and Assessment Method Preferences (4 Questions) assessed on a 5-point Likert Scale.

\section{Statistical Analysis}

The collected data was analysed using SPSS version 16 for descriptive and inferential statistics using Student Paired t test to check for difference in opinion of students regarding the 2 assessment methods. Student Unpaired t test was used to observe the difference in opinion between $3^{\text {rd }}$ and $4^{\text {th }}$ BDS students on the various domains of Assessment.

\section{RESULTS}

143 of the 162 students participated in the study giving a response rate of $88.2 \%$. Among the study participants, 101 $(70.6 \%)$ were females, 42 (24.9\%) were males, 67 (46.9\%) were $3^{\text {rd }}$ BDS Students and 76 (53.1\%) were $4^{\text {th }}$ BDS Students.

On assessing the role of Formative and Summative Assessment in Enhancing Student Learning and Competencies, $72 \%$ and $33.6 \%$ Students were of the opinion that formative assessment helped in long term retention of the concepts and exploration of ideas as compared to Summative Assessment. In addition, $41.3 \%$ and $23.1 \%$ students felt that the overall performance of students was enhanced by Formative assessment and Summative Assessment respectively (Table I). For the domain Enhanced learning and competencies, the mean value for Formative Assessment was $14.14+3.44$ and Summative assessment was $13.71+3.47$ and this difference was statistically Significant ( $\mathrm{p}=0.002$ ) (Table II). A statistically significant difference was observed in the opinion of students, wherein the $4^{\text {th }}$ BDS students were more inclined to Formative 
Assessment in terms of Enhancing learning and competencies (Table III).

In terms of merits and demerits of assessment, 45.5\% students felt that their Workload and anxiety was increased by Summative Assessment. However, $32.9 \%$ students were of the opinion that Formative Assessment affected their personal life but was an effective means of obtaining regular feedback (24.5\%) (Table I). For the domain Merits and Demerits of Assessment, the mean value for Formative Assessment was $15.06+2.62$ and Summative assessment was $13.75+2.58$ and this difference was statistically Significant $(\mathrm{p}=0.000)$ (Table II). No statistically significant difference was observed in the opinion of $3^{\text {rd }}$ and $4^{\text {th }}$ BDS students (Table III).

73.4\% students preferred Formative assessment over Summative Assessment. On analysing the student's preferences and reasons on their choices regarding the mode of assessment, 58.7\% preferred Short essays in Theory Exams as they felt that essay encourages wider reading, critical thinking and is more enjoyable and rewarding if the topic is understood properly. $58.57 \%$ students preferred Objective Structured Clinical Examination (OSCE) as a mode of Practical examination as they felt that it was reliable, fair and that skill performance and behaviour of the students could be assessed in a short time.

\begin{tabular}{|c|c|c|c|c|c|c|c|c|c|c|}
\hline & \multicolumn{5}{|c|}{ Formative Assessment - \% (n) } & \multicolumn{5}{|c|}{$\begin{array}{c}\text { Summative Assessment - \% } \\
\text { (n) }\end{array}$} \\
\hline & 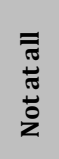 & 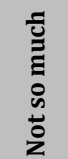 & 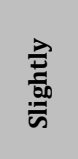 & $\begin{array}{l}\frac{1}{\pi} \\
\frac{0}{0} \\
\frac{0}{2} \\
\Sigma\end{array}$ & 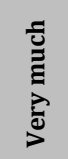 & $\begin{array}{l}\text { స } \\
\stackrel{\text { సँ }}{3} \\
\stackrel{0}{Z} \\
z\end{array}$ & 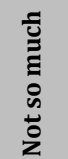 & 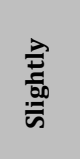 & 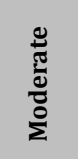 & 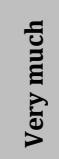 \\
\hline \multicolumn{11}{|c|}{ Domain 1-Student Learning and Competencies } \\
\hline $\begin{array}{l}\text { Long term } \\
\text { retention of } \\
\text { concepts }\end{array}$ & $\begin{array}{c}7 \\
(4.9)\end{array}$ & $\begin{array}{c}18 \\
(126)\end{array}$ & $\begin{array}{c}29 \\
(20.3)\end{array}$ & $\begin{array}{c}17 \\
(11.9)\end{array}$ & $\begin{array}{c}72 \\
(50.3)\end{array}$ & $\begin{array}{c}4 \\
(2.8)\end{array}$ & $\begin{array}{c}23 \\
(16.1)\end{array}$ & $\begin{array}{c}51 \\
(35.7)\end{array}$ & $\begin{array}{c}46 \\
(32.2)\end{array}$ & $\begin{array}{c}19 \\
(13.3)\end{array}$ \\
\hline $\begin{array}{l}\text { Practical } \\
\text { Application }\end{array}$ & $\begin{array}{c}6 \\
(4.2)\end{array}$ & $\begin{array}{c}16 \\
(11.2)\end{array}$ & $\begin{array}{c}33 \\
(23.1)\end{array}$ & $\begin{array}{c}19 \\
(13.3)\end{array}$ & $\begin{array}{c}69 \\
(48.3)\end{array}$ & $\begin{array}{c}4 \\
(2.8)\end{array}$ & $\begin{array}{c}31 \\
(21.7)\end{array}$ & $\begin{array}{c}41 \\
(28.7)\end{array}$ & $\begin{array}{c}50 \\
(35.0)\end{array}$ & $\begin{array}{c}17 \\
(11.9)\end{array}$ \\
\hline $\begin{array}{c}\text { Explore } \\
\text { ideas }\end{array}$ & $\begin{array}{c}9 \\
(6.3)\end{array}$ & $\begin{array}{c}12 \\
(8.4)\end{array}$ & $\begin{array}{c}53 \\
(37.1)\end{array}$ & $\begin{array}{c}21 \\
(14.7)\end{array}$ & $\begin{array}{c}48 \\
(33.6)\end{array}$ & $\begin{array}{c}6 \\
(4.2)\end{array}$ & $\begin{array}{c}17 \\
(11.9)\end{array}$ & $\begin{array}{c}52 \\
(36.4)\end{array}$ & $\begin{array}{c}47 \\
(32.9)\end{array}$ & $\begin{array}{c}21 \\
(14.7)\end{array}$ \\
\hline $\begin{array}{c}\text { Overall } \\
\text { performance }\end{array}$ & $\begin{array}{c}7 \\
\text { e (4.9) }\end{array}$ & $\begin{array}{c}14 \\
(9.8)\end{array}$ & $\begin{array}{c}32 \\
(22.4)\end{array}$ & $\begin{array}{c}31 \\
(21.7)\end{array}$ & $\begin{array}{c}59 \\
(41.3)\end{array}$ & $\begin{array}{c}6 \\
(4.2)\end{array}$ & $\begin{array}{c}50 \\
(35.0)\end{array}$ & $\begin{array}{c}36 \\
(25.2)\end{array}$ & $\begin{array}{c}18 \\
(12.6)\end{array}$ & $\begin{array}{c}33 \\
(23.1)\end{array}$ \\
\hline \multicolumn{11}{|c|}{ Domain 2: Drawbacks } \\
\hline $\begin{array}{c}\text { Workload\& } \\
\text { anxiety }\end{array}$ & $\begin{array}{c}5 \\
(3.5)\end{array}$ & $\begin{array}{c}8 \\
(5.6)\end{array}$ & $\begin{array}{c}34 \\
(23.8)\end{array}$ & $\begin{array}{c}47 \\
(32.9)\end{array}$ & $\begin{array}{c}49 \\
(34.3)\end{array}$ & $\begin{array}{c}6 \\
(4.2)\end{array}$ & $\begin{array}{c}10 \\
(7.0)\end{array}$ & $\begin{array}{c}27 \\
(18.9)\end{array}$ & $\begin{array}{c}35 \\
(24.5)\end{array}$ & $\begin{array}{c}65 \\
(45.5)\end{array}$ \\
\hline $\begin{array}{l}\text { Personal life } \\
\text { affected }\end{array}$ & $\begin{array}{c}4 \\
(2.8)\end{array}$ & $\begin{array}{c}19 \\
(13.3)\end{array}$ & $\begin{array}{c}35 \\
(24.5)\end{array}$ & $\begin{array}{c}38 \\
(26.6)\end{array}$ & $\begin{array}{c}47 \\
(32.9)\end{array}$ & $\begin{array}{c}9 \\
(6.3)\end{array}$ & $\begin{array}{c}24 \\
(16.8)\end{array}$ & $\begin{array}{c}52 \\
(36.4)\end{array}$ & $\begin{array}{c}31 \\
(21.7)\end{array}$ & $\begin{array}{c}27 \\
(18.9)\end{array}$ \\
\hline Grading & $\begin{array}{c}8 \\
(5.6)\end{array}$ & $\begin{array}{c}10 \\
(7.0)\end{array}$ & $\begin{array}{c}35 \\
(24.5)\end{array}$ & $\begin{array}{c}49 \\
(34.3)\end{array}$ & $\begin{array}{c}41 \\
(28.7)\end{array}$ & $\begin{array}{c}11 \\
(7.7)\end{array}$ & $\begin{array}{c}16 \\
(11.2)\end{array}$ & $\begin{array}{c}57 \\
(39.9)\end{array}$ & $\begin{array}{c}35 \\
(24.5)\end{array}$ & $\begin{array}{c}24 \\
(16.8)\end{array}$ \\
\hline Feedback & $\begin{array}{c}8 \\
(5.6)\end{array}$ & $\begin{array}{c}8 \\
(5.6)\end{array}$ & $\begin{array}{c}37 \\
(25.9)\end{array}$ & $\begin{array}{c}55 \\
(38.5)\end{array}$ & $\begin{array}{c}35 \\
(24.5)\end{array}$ & $\begin{array}{c}12 \\
(8.4)\end{array}$ & $\begin{array}{c}18 \\
(12.6)\end{array}$ & $\begin{array}{c}67 \\
(46.9)\end{array}$ & $\begin{array}{c}31 \\
(21.7)\end{array}$ & $\begin{array}{c}15 \\
(10.5)\end{array}$ \\
\hline \multicolumn{11}{|c|}{ Domain 4: Curriculum } \\
\hline $\begin{array}{l}\text { Cover } \\
\text { Syllabus }\end{array}$ & $\begin{array}{c}6 \\
(4.2)\end{array}$ & $\begin{array}{c}13 \\
(9.1)\end{array}$ & $\begin{array}{c}42 \\
(29.4)\end{array}$ & $\begin{array}{c}53 \\
(37.1)\end{array}$ & $\begin{array}{c}29 \\
(20.3)\end{array}$ & $\begin{array}{c}2 \\
(1.4)\end{array}$ & $\begin{array}{c}16 \\
(11.2)\end{array}$ & $\begin{array}{c}54 \\
(37.8)\end{array}$ & $\begin{array}{c}45 \\
(31.5)\end{array}$ & $\begin{array}{c}26 \\
(18.2)\end{array}$ \\
\hline $\begin{array}{l}\text { Preference } \\
\text { of Students }\end{array}$ & & & $\begin{array}{r}105 \\
(73.4)\end{array}$ & & & & & $\begin{array}{c}38 \\
(26.6)\end{array}$ & & \\
\hline \multicolumn{11}{|c|}{$\begin{array}{c}\text { Table I. Preferences of Students Regarding } \\
\text { Formative and Summative Assessment }\end{array}$} \\
\hline
\end{tabular}

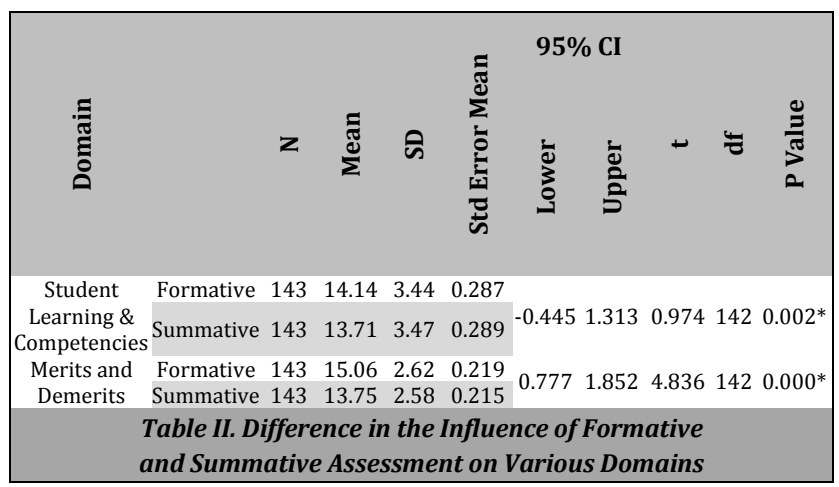

\begin{tabular}{|c|c|c|c|c|c|c|c|c|}
\hline Domain & & $\mathbf{N}$ & Mean & SD & $\begin{array}{l}\text { Std. } \\
\text { Error } \\
\text { Mean }\end{array}$ & t & df & $\begin{array}{c}P \\
\text { Value }\end{array}$ \\
\hline \multirow{2}{*}{$\begin{array}{l}\text { Student Learning \& } \\
\text { Competencies } \\
\text { _Formative }\end{array}$} & year & 67 & 13.63 & 3.64 & 0.444 & \multirow[b]{2}{*}{-1.684} & \multirow[b]{2}{*}{141} & \multirow[b]{2}{*}{$0.004 *$} \\
\hline & $4^{\text {th }}$ Year & 76 & 14.59 & 3.22 & 0.369 & & & \\
\hline Student Learning \& & $3^{\text {rd }}$ year & 67 & 14.45 & 3.62 & 0.442 & \multirow[b]{2}{*}{2.444} & \multirow[b]{2}{*}{141} & \multirow[b]{2}{*}{$0.016^{*}$} \\
\hline $\begin{array}{l}\text { Competencies } \\
\text { Summative }\end{array}$ & $4^{\text {th }}$ Year & 76 & 13.05 & 3.20 & 0.367 & & & \\
\hline $\begin{array}{l}\text { Merits and Demerits } \\
\text { Formative }\end{array}$ & $\begin{array}{l}3^{\text {rd }} \text { year } \\
4^{\text {th }} \text { Year }\end{array}$ & $\begin{array}{l}67 \\
76\end{array}$ & $\begin{array}{l}15.25 \\
14.89\end{array}$ & $\begin{array}{l}2.79 \\
2.45\end{array}$ & $\begin{array}{l}0.341 \\
0.281\end{array}$ & 0.817 & 141 & 0.415 \\
\hline $\begin{array}{l}\text { Merits and Demerits } \\
\text { _Summative }\end{array}$ & $\begin{array}{l}3^{\text {rd }} \text { year } \\
4^{\text {th }} \text { Year }\end{array}$ & $\begin{array}{l}67 \\
76\end{array}$ & $\begin{array}{l}13.70 \\
13.79\end{array}$ & $\begin{array}{l}2.54 \\
2.62\end{array}$ & $\begin{array}{l}0.311 \\
0.301\end{array}$ & -0.203 & 141 & 0.840 \\
\hline \multicolumn{9}{|c|}{ Table III. Difference in Preferences of $3^{\text {rd }}$ and $4^{\text {th }}$} \\
\hline
\end{tabular}

\section{DISCUSSION}

In this era where the quest for improved knowledge is rising, the information gleaned from assessment is extremely valuable as it provides information about the levels of understanding that students are reaching through a continuous approach[1]. With a fast progressing and competitive education system, Formative and Summative assessments are deeply embedded in the Curriculum. Whilst both Assessment forms serve distinct educational purposes, their divergence in delivering knowledge and modulating the curriculum still remains unrequited. Since the influence of assessment on curriculum and instruction is now widely acknowledged, educators, policymakers, and other stakeholders are adopting other assessment methods over summative assessment, as a tool for educational reform.[9] While enforcing this change obtaining the perceptions of stakeholders, especially students play a vital role in reforming the curriculum.

In the present study it was found that $72 \%$ students felt that Formative Assessment helped in retaining the concepts learnt for a longer time as compared to Summative Assessment. It was also found that Students had an opportunity to explore new ideas in Formative Assessment rather than being spoon fed as in Summative Assessment. The findings of the study are in consensus with the studies by Evans et al and Yorke et al wherein it was found that students felt that Formative Assessment was more favourable in terms of enhancing student learning.[10,11] This can be owed to the fact that Formative Assessment indulges students in a continuous learning process enhancing their skills and Overall learning.

On analysing the merits and demerits of the 2 assessment methods in the present study, it was found that $24.5 \%$ students felt that Formative Assessment was a success due to the regular feedback mechanism. This finding was in par with a study conducted by Peria et al among pre-graduate students of health sciences wherein it was concluded that regular feedback to the students determined their greater involvement in the learning process.[12] A similar study by Das et al among Basic Science medical Students also spelled out the fact that $51.5 \%$ students felt that Formative Assessment was a means of regular feedback for them.[13] However, the present study findings also highlighted that students were of the opinion that both Formative and Summative Assessment increased their workload and affected their personal life. These responses are similar to a study by David Gibjels et al, 
where students perceived Formative Assessment to increase the workload of the course.[14]

Overall the present study showed that $73.4 \%$ students preferred Formative Assessment over Summative Assessment. The findings are in par with a study by Panchbhai et al wherein Faculty and Students perceived Formative Assessment practises to be a satisfactory method of Evaluation.[15] This can be owed to the fact that Formative Assessment enhances Overall Learning and is a boon for students as they receive regular feedback which increases their scope for improvement. In the present study $58.7 \%$ Students preferred Short Essay type questions in Theory examinations and Objective Structured Clinical Examinations in Practical Exams.

These results were in contrary to the studies conducted by Aalaei et al and Nandan et al wherein the students preferred Multiple Choice questions as a mode of assessment in Theory Examinations.[16,17] Multiple choice Questions usually involve no real time critique or analysis and is easier to prepare as it is less time consuming and effortless. However, regarding the Mode of Assessment in Practical examinations, the study findings were similar to a study by Awaisu et al wherein $80 \%$ of the students found OSCE to be helpful in highlighting areas of weaknesses in their clinical competencies.[18]

The present study was conducted amongst dental students in a single institution. In addition, the responses of the participants were obtained through a questionnaire, thus there may be a probability of the responses being influenced by Social Desirability Bias.

The need of the hour is to train the budding youths as innovative problem-solvers and not as rote-learners. But the suppleness of the current curriculum fails to measure the real potential of the learners foregoing the individuality and creativity of the learners by taking into account only the marks scored in the final examination. This backlash effect of examination has taken its toll on the pedagogical principles of teaching and learning compromising the whole educational system.

Majority of the students preferred Formative Assessment as a mode of evaluation over Summative Assessment. Thus, there is a strong evidence base that a curriculum designed with appropriate amalgamation between Formative and Summative Assessment is required.

Financial or Other Competing Interests: None.

\section{CONCLUSIONS}

This study may be compelling evidence to curriculum developers and policy makers in bringing about curricular changes associated with the upgradation and implementation of the assessment strategies in the dental curriculum. In this direction, the curriculum developers should develop a range of policies for promoting the integration of Formative and Summative Assessment and setting it as a priority in the curriculum. This encourages more research involving all the stakeholders, in all the dental colleges to strengthen the existing evidence base, thus enhancing the delivery of education to its best.

\section{REFERENCES}

[1] Wiliam D. Assessment: the bridge between teaching and learning. Voices form the Middle 2013;21(2):15-20.

[2] Ogange BO, Agak J, Okelo KO, et al. Student Perceptions of the effectiveness of formative assessment in an online learning environment. Open Praxis 2018;10(1):29-39.

[3] Mohabuth AQ, Ahmad SM. The effectiveness of summative assessment in practice learning. International Institute of Social and Economic Sciences 2015. https://ideas.repec.org/p/sek/iacpro/2705029.html

[4] DCI. Regulations of the Dental Council of India. Dental Council of India 1982. http://www.dciindia.gov.in/Rule_Regulation/DCI_Regul ations_1956.pdf

[5] Nagda SJ. Changing trends in dental education - Paradigm shift. J Dent Spec 2015;3(1):86-8.

[6] Lagali-Jirge V. Need for paradigm shift in Indian dental education: a case for change toward competency-based education. J Indian Acad Oral Med Radiol 2015;27(2):2306.

[7] Srivastava T, Waghmare LS, Vagha SJ, et al. Effective feedback practices in formative assessment: recognizing the relevance. Journal of Education and Practice 2013;4(11):47-55.

[8] Chaudhary SVS, Dey N. Assessment in open and distance learning system (ODL): a challenge. Open Praxis 2013;5(3):207-16.

[9] Birenbaum M, DeLuca C, Earl L. International trends in the implementation of assessment for learning: implications for policy and practice. Policy Futur Educ 2015;13(1):117-40.

[10] Yorke M. Formative assessment and its relevance to retention. High Educ Res Dev 2001;20(2):115-26.

[11] Evans DJ, Zeun P, Stanier RA. Motivating student learning using a formative assessment journey. J Anat 2014;224(3):296-303.

[12] Carrillo-de-la-Peña MT, Baillès E, Caseras X, et al. Formative assessment and academic achievement in pregraduate students of health sciences. Adv Health Sci Educ Theory Pract 2009;14(1):61-7.

[13] Das S, Alsalhanie KM, Nauhria S, et al. Impact of formative assessment on the outcome of summative assessment - a feedback based cross sectional study conducted among basic science medical students enrolled in MD program. Asian J Med Sci 2017;8(4):38-43.

[14] Gijbels D, Dochy F. Students' assessment preferences and approaches to learning: can formative assessment make a difference? Educational Studies 2006;32(4):399-409.

[15] Panchbhai A, Vagha S, Bhowate R. Perception of students and faculties regarding the formative assessment examinations in dental college in India. J Educ Ethics Dent 2014;4(2):47-53.

[16] Aalaei S, Ahmadi MAT, Aalaei A. A comparison of multiplechoice and essay questions in the evaluation of dental students. Int J Adv Biotechnol Res 2016;7(5):1674-80.

[17] Nandan TM, Latha G, Selvakumar D, et al. Comparison of essay type and multiple choice questions for theoretical formative assessment among second phase MBBS students in microbiology. Int J Curr Microbiol Appl Sci 2017;6(5):1529-37. 
[18] Awaisu A, Mohamed MHN, Al-Efan QAM. Perception of pharmacy students in malaysia on the use of objective structured clinical examinations to evaluate competence. Am J Pharm Educ 2007;71(6):118. 